\title{
Immunohistochemical analysis of beta- catenin, E-cadherin and p53 in canine gastrointestinal epithelial tumors
}

\author{
Tsubasa SAITO ${ }^{1)}$, James K. CHAMBERS'), Ko NAKASHIMA ${ }^{2)}$, Kazumi NIBE ${ }^{3)}$, \\ Koichi OHNO ${ }^{4)}$, Hajime TSUJIMOTO ${ }^{4)}$, Kazuyuki UCHIDA ${ }^{1) *}$ and \\ Hiroyuki NAKAYAMA ${ }^{1)}$ \\ 1)Laboratory of Veterinary Pathology, Graduate School of Agricultural and Life Sciences, The University of Tokyo, \\ 1-1-1 Yayoi, Bunkyo-ku, Tokyo 113-8657, Japan \\ 2) Japan Small Animal Medical Center, 2-27-4 Nakatomi-minami, Tokorozawa, Saitama 359-0003, Japan \\ 3) Japan Animal Referral Medical Center, 2-5-8 Kuji, Takatsu-ku, Kawasaki, Kanagawa 213-0032, Japan \\ 4)Department of Veterinary Internal Medicine, Graduate School of Agricultural and Life Sciences, The University \\ of Tokyo, 1-1-1 Yayoi, Bunkyo-ku, Tokyo 113-8657, Japan
}

J. Vet. Med. Sci.

82(9): 1277-1286, 2020

doi: 10.1292/jvms.20-0297

Received: 19 May 2020

Accepted: 2 July 2020

Advanced Epub:

13 July 2020

\begin{abstract}
Wnt/beta-catenin signaling, E-cadherin and p53 reportedly play important roles in the development and/or progression of human gastrointestinal cancer. The present study evaluated the roles of beta-catenin, E-cadherin and p53 in canine gastrointestinal tumors. Endoscopic biopsy or surgically resected samples, a total of 131, including 38 gastric, 13 small intestinal and 80 large intestinal tumors, were obtained from 95 dogs. Those specimens were examined pathologically. Immunohistochemically, nuclear beta-catenin expression was found in $88 \%$ (42/48) of polypoid type adenocarcinomas. Most cases of non-polypoid type adenocarcinomas lacked nuclear expression of beta-catenin with the exception of one case $(6 \%$, $1 / 17)$. Nuclear beta-catenin expression was not observed in signet ring cell carcinomas $(0 / 15)$, mucinous adenocarcinomas $(0 / 7)$ and undifferentiated carcinomas $(0 / 4)$. The findings indicate that nuclear translocation of beta-catenin is closely related to the development of polypoid type adenocarcinomas but not that of non-polypoid type malignant tumors. The immunoreactivity of E-cadherin for tumor cells tended to decline overall in most of cases including benign tumors. Significant immunoreactivity for p53 was not found in $61 \%$ of tumors examined (80/131), including malignant tumors $(63 \%, 57 / 91)$, while intense p53-immunoreactivity was rarely found in a few cases of malignant tumors $(8 \%, 7 / 91)$. We could not conclude clearly significant correlations between histopathological tumor types and immunohistochemical results of E-cadherin or p53. This paper indicates the importance of the nuclear translocation of beta-catenin for the tumorigenesis of canine intestinal polypoid type adenocarcinomas, especially in the colorectum.
\end{abstract}

KEY WORDS: beta-catenin, carcinogenesis, dog, gastrointestinal neoplasm, immunohistochemistry

The adenoma-carcinoma sequence, the major pathway of colorectal tumorigenesis in humans, is considered to require the accumulation of genetic changes [57]. Inactivation of the adenomatous polyposis coli $(A P C)$ tumor suppressor gene is the first event in this sequence resulting in colorectal adenoma formation [20]. Mutations in $A P C$ were discovered in patients with human familial adenomatous polyposis (FAP) $[13,26,40]$ and were found in more than $80 \%$ of sporadic colorectal adenomas and carcinomas [27]. APC mutations are associated with an accumulation of intracellular beta-catenin protein, which leads to loss of control of normal beta-catenin signaling [38]. Beta-catenin accumulates in the cytoplasm and nucleus because the mutated $A P C$ does not bind axin and reduces degradation of beta-catenin [18]. Furthermore, in colorectal tumors, beta-catenin mutations are also detected and activation of beta-catenin-Tcf signaling has been reported [36]. The participation of beta-catenin in intestinal tumorigenesis has been also evaluated in experimental and domestic animals [33, 54]. Consequently, the tumors in the FAP patients or $A P C^{\mathrm{min}}$ mice are generally formed by polypoid growth and the tumorigenesis is considered to be through the adenomacarcinoma sequence [41]. We previously showed that Jack Russell Terriers and Miniature Dachshunds were the breeds with the highest predisposition for gastrointestinal tumors, and Jack Russel Terrier was frequently involved in polypoid formed tumors

*Correspondence to: Uchida, K.: auchidak@mail.ecc.u-tokyo.ac.jp (Supplementary material: refer to PMC https://www.ncbi.nlm.nih.gov/pmc/journals/2350/) (O2020 The Japanese Society of Veterinary Science

This is an open-access article distributed under the terms of the Creative Commons Attribution Non-Commercial No Derivatives (by-nc-nd) License. (CC-BY-NC-ND 4.0: https://creativecommons.org/licenses/by-nc-nd/4.0/) 
[48]. Recently, a somatic mutation and loss of the wild-type $A P C$ allele have been reported in the canine breed with gastrointestinal tumors [62]. By contrast, adenocarcinoma shows not only polypoid formation but also occasionally lacked polypoid characteristics and the lesions are flat or depressed in humans and dogs $[48,52]$. These carcinomas are considered to be de novo because the lesions were small and develop without any intervening precursor lesion [7, 30]. Morphologically, the adenoma-carcinoma sequence or de novo tumorigenesis pathway is classified as polypoid growth (PG) type and non-polypoid growth (NPG) type, respectively [21, 49]. NPG carcinomas grow rapidly, resulting in largely advanced carcinoma of the NPG type [31, 35]. In de novo carcinogenesis, although little is known about the genetic alterations [16, 37, 61], the involvement of APC and KRAS is considered to be rare $[34,55,60]$.

E-cadherin is a calcium-dependent cell-cell adhesion molecule and composed of an adherence junction with alpha-, beta-, and p120-catenin. E-cadherin and these adhesion molecules play an important role in maintaining the epithelial contexture and tumor-suppressive action [22, 43, 53, 59]. Especially, E-cadherin is widely known to play a key role in tumor suppression [39] and/or infiltrative growth, metastasis and poor prognosis [3]. In the case of cancer progression, cancer cells must become detached from neighboring cells, invade through the basement membrane and then migrate into the surrounding tissues. Since mutation of E-cadherin is detected in various malignant tumors [45], cell-cell adhesion molecules may play an important role in cancer invasion and metastasis $[11,56]$. Previous studies showed that various tumors [51], including gastric [32, 50] and colorectal [25, 42] often lose E-cadherin expression by immunohistochemistry (IHC). Although there are some previous studies on the role of E-cadherin in canine gastrointestinal tumors $[2,33,46]$, little is understood about its role.

In the $\mathrm{p} 53$ tumor suppressor gene, gene mutation and protein accumulation are involved in the conversion of adenoma to early carcinoma $[24,44]$. Wild-type p53 is an unstable protein with a short half-life for its detection by IHC, but mutant p53 can accumulate within tumor cells creating a stable target for IHC [1, 10, 14, 23]. Indeed, IHC has been widely used as a useful method for mutant $\mathrm{p} 53$ detection in humans $[8,9,28,47]$. Accumulation of the p53 protein was reportedly also detected in various canine tumors by IHC $[4,5,12,15]$. However, there are some reports that unlike human colorectal tumors malignant progression does not depend on the acquisition of p53 mutations in canine intestinal tumors $[33,58]$.

Previously, we described the histopathological features, age, sex, and breed predisposition of canine gastrointestinal epithelial tumors [48]. This paper focuses on immunohistochemical features of these tumors. The aim of this study is to investigate the relationship between histopathological features and major makers of oncogenesis in canine gastrointestinal epithelial tumors. The canine gastrointestinal tumors, a total of 131, were immunohistochemically evaluated for beta-catenin, E-cadherin, and p53.

\section{MATERIALS AND METHODS}

\section{Cases}

Endoscopic biopsy or surgical excision was performed in 95 dogs at the Veterinary Medical Center of the University of Tokyo, the Japan Small Animal Medical Center, and Japan Animal Referral Medical Center between 2013 and 2016. As histopathological cases, 131 specimens of neoplastic lesions from these dogs were used.

\section{Histological examinations}

All the samples were fixed in 10\% neutral buffered formalin. Paraffin sections of $4 \mu \mathrm{m}$, were stained with hematoxylin and eosin (HE). The specimens were diagnosed by two experienced Japanese College of Veterinary Pathology certified veterinary pathologists (J.K.C and K.U) at the Department of Veterinary Pathology of the University of Tokyo. Each lesion was classified according to the "WHO histological classification of tumors of the alimentary system of domestic animals" [17] with modification as follows. Acinar-, papillary- and tubulopapillary adenocarcinoma were classified into PG (Fig. 1) or NPG (Fig. 2) adenocarcinoma, because we focused on histological growth patterns. The PG/NPG classification was based on histological classifications of human intestinal tumors [49]. In brief, PG adenocarcinoma formed a protuberant mass that included pedunculated lesions and sessile or broad-based lesions. NPG adenocarcinoma formed a flat or depressed lesion without intramucosal protuberant growth. Adenomas $(n=40)$, PG adenocarcinomas $(n=48)$, NPG adenocarcinomas $(n=17)$, signet ring cell carcinomas (SRC, $\mathrm{n}=15$ ), mucinous adenocarcinomas (MUC, $\mathrm{n}=7$ ) and undifferentiated carcinomas (UND, n=4) were evaluated, and Figs. 1 to 5 show typical histopathological features of these tumors, respectively. These specimens were subjected to IHC for beta-catenin, E-cadherin and p53. The details of the histopathological features, age, sex, and breed predisposition were described in the previous paper [48].

\section{Immunohistochemistry}

Paraffin sections were de-paraffinized and treated with 3\% hydrogen peroxidase in methanol at room temperature for 5 min and then incubated with $8 \%$ skimmed milk in Tris-buffered saline at $37^{\circ} \mathrm{C}$ for $40 \mathrm{~min}$ to block nonspecific reactions. The primary antibodies used were as follows: mouse anti-beta-catenin monoclonal antibody $(1: 1,000$, clone 14/Beta-Catenin, BD Transduction Laboratories, San Jose, CA, USA), mouse anti-E-cadherin monoclonal antibody (1:1,000, 36/E-Cadherin, BD Transduction Laboratories) and rabbit anti-p53 polyclonal antibody (1:50, FL-393, Santa Cruz Biotechnology, Santa Cruz, CA, USA). Antigen retrieval was performed by heating the sections using an autoclave at $121^{\circ} \mathrm{C}$ for $10 \mathrm{~min}$, in $\mathrm{pH} 6.0$ citrate buffer for beta-catenin and E-cadherin and in Dako high $\mathrm{pH}$ antigen retrieval solution (Dako, Tokyo, Japan) for p53. The sections were reacted with each primary antibody in a moist chamber at $4{ }^{\circ} \mathrm{C}$ overnight. After washing, the sections were treated with the Dako Envision Plus Kit (Dako). In order to visualize the immunoreactions, a 3-3'-diaminobenzidine (Dojindo, Kumamoto, Japan) solution containing 


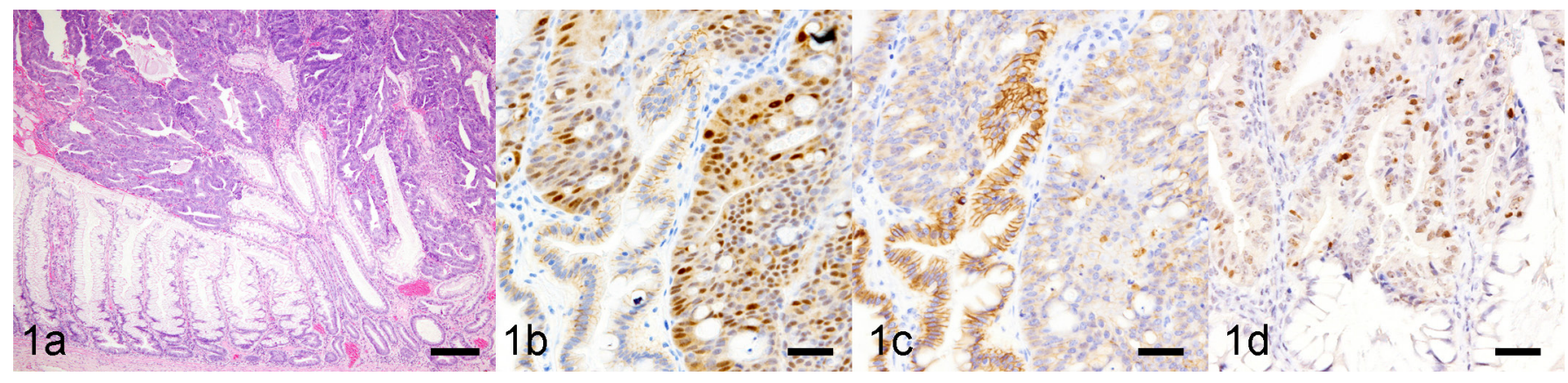

Fig. 1. Polypoid growth type of adenocarcinoma, sample number 119. Dog, large intestine. (a) The neoplastic lesions protrude into the lumen. Hematoxylin and eosin stain (HE). Bar, $200 \mu \mathrm{m}$. (b) Nuclei of neoplastic cells are positive for beta-catenin. Score 3. Immunohistochemistry (IHC). Bar, $200 \mu \mathrm{m}$. (c) Cell membrane of neoplastic cells is weakly positive for E-cadherin. Score 3. IHC. Bar, $40 \mu \mathrm{m}$. (d) Nuclei of neoplastic cells are sporadically positive for p53. Score 1 . IHC. Bar, $40 \mu \mathrm{m}$.
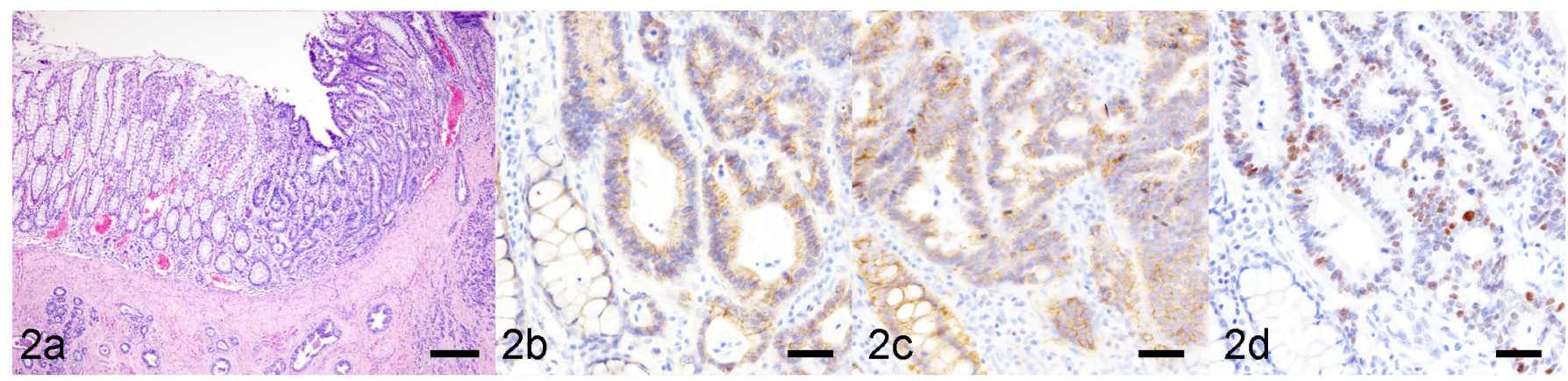

Fig. 2. Non-polypoid growth type of adenocarcinoma, sample number 122. Dog, large intestine. (a) The surface of the mucosa is flat, and the tumor cells invade into the submucosal layer. Hematoxylin and eosin stain (HE). Bar, $200 \mu \mathrm{m}$. (b) Nuclei of neoplastic cells are negative for beta-catenin. Score 0. Immunohistochemistry (IHC). (c) Cell membrane of neoplastic cells is heterogeneously positive for E-cadherin. Score 1. IHC. (d) Nuclei of neoplastic cells are sporadically positive for p53. Score 2. IHC. (b-d) Bar, $40 \mu \mathrm{m}$.

$0.03 \% \mathrm{H}_{2} \mathrm{O}_{2}$ was used. All slides were counterstained with Mayer's hematoxylin. For negative controls, the primary antibody was omitted from the reaction. Beta-catenin and p53 were assessed using nuclear-positive ratios and E-cadherin was assessed by the area of reduction for membranous-positive-intensity. The slides were scored based on the proportion of cells affected as follows: score $0,<1 \%$ tumor cells nuclei showing immunoreactivity; score 1, 1-25\% showing immunoreactivity; score 2, 26-50\% showing immunoreactivity; score $3,>50 \%$ showing immunoreactivity for nuclear beta-catenin and $\mathrm{p} 53$, and on the contrary the ratio of cells showing a reduced area of immunoreactivity for E-cadherin.

\section{Statistical analysis}

Statistical analysis was performed using the SAS Release 9.1.3 (SAS Institute Inc., Cary, NC, USA). Comparisons of the means of different groups were performed with a one-way analysis of variance, followed by Tukey's honestly significant difference test. $P$-values of less than 0.05 were considered statistically significant.

\section{RESULTS}

\section{Immunoreactivity of beta-catenin}

Immunohistochemically, beta-catenin was located on the cell membrane of normal epithelial cells. In the case of tumors, immunoreactivity representing nuclear beta-catenin expression was evaluated as the significant finding. The results of beta-catenin immunoreactivity for each tumor are represented in Table 1 and Supplementary Table 1. Nuclear expression of beta-catenin in tumor cells was observed in $20 \%(1 / 5)$ of gastric- and $94 \%(33 / 35)$ of colorectal adenomas. In more than half (55\%, 22/40) of adenomas, the results were evaluated as score 1 , and there were no cases evaluated as score 2 or 3 in gastric tumors. In PG adenocarcinoma, nuclear expression of beta-catenin was observed in $45 \%(5 / 11)$ of gastric, 100\% (3/3) of small intestine and $100 \%$ (34/34) of colorectal tumors (Fig. 1b). Although the gastric (Fig. 6a, 6b) and intestinal (Fig. 7a, 7b) PG tumors were similar morphological structures the immune-response was different (Figs. 6c, 7c, Table 1). Especially in the colorectal tumors, $47 \%$ $(16 / 34)$ of PG adenocarcinomas were evaluated as score 3, the score was higher than the gastric tumors. In contrast, the nuclear expression of beta-catenin was not found in any NPG/diffuse type of tumors including NPG (1/17, Fig. 2b), SRC (0/15, Fig. 3b), 

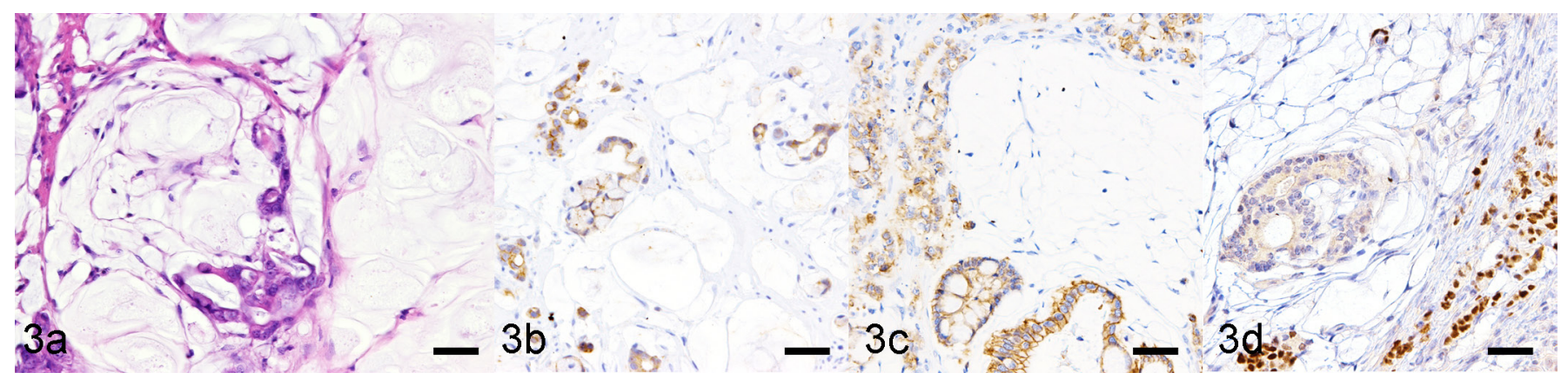

Fig. 3. Mucinous adenocarcinoma, sample number 46. Dog, small intestine. (a) Neoplastic cells proliferate with the outer cellular mucin into the submucosa, and neoplastic cells form solitary or gland-like structures. Hematoxylin and eosin stain (HE). (b) Nuclei of neoplastic cells are negative for beta-catenin. Score 0. Immunohistochemistry (IHC). (c) The immunoreactivity for E-cadherin is reduced or lost in the cell membrane of neoplastic cells forming solitary neoplastic foci, while neoplastic cells with glandular or tubular structures are intensely immunopositive for E-cadherin. Score 2. IHC. (d) The nuclei of the neoplastic cells forming solitary neoplastic foci show positive immunoreactivity for p53. The nuclei of the neoplastic cells with glandular or tubular structures are negative for p53. Score 1. IHC. (a-d) Bar, $40 \mu \mathrm{m}$.
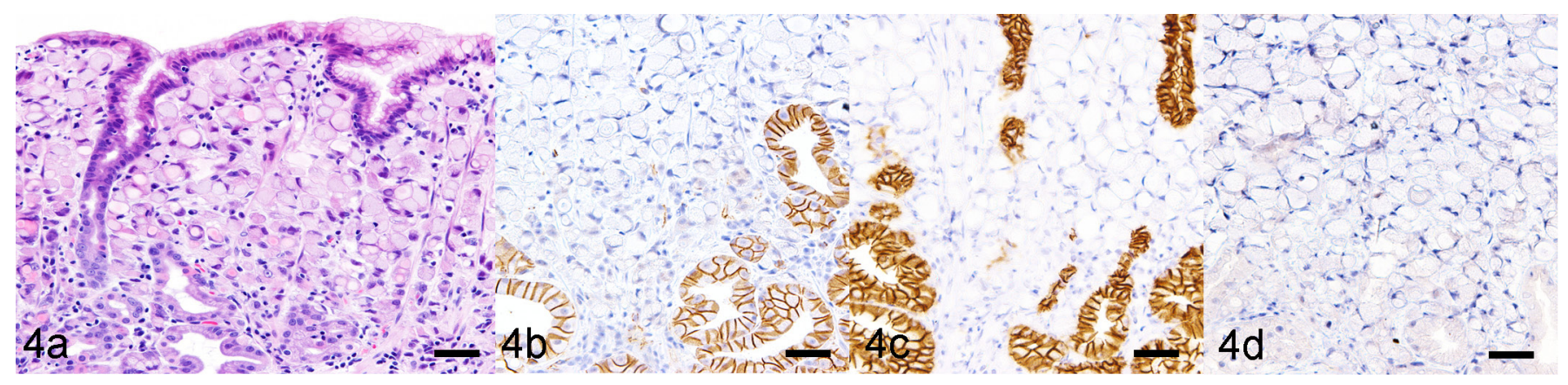

Fig. 4. Signet ring cell carcinoma, Sample number 32. Dog, stomach. (a) "Signet ring" formed neoplastic cells are diffusely observed in the lamina propria. Hematoxylin and eosin stain (HE). (b) Nuclei of neoplastic cells are negative for beta-catenin. Score 0. Immunohistochemistry (IHC). (c) Cell membrane of neoplastic cells is completely negative for E-cadherin. Score 3. IHC. (d) Nuclei of neoplastic cells are negative for p53. Score 0. IHC. (a-d) Bar, $40 \mu \mathrm{m}$.

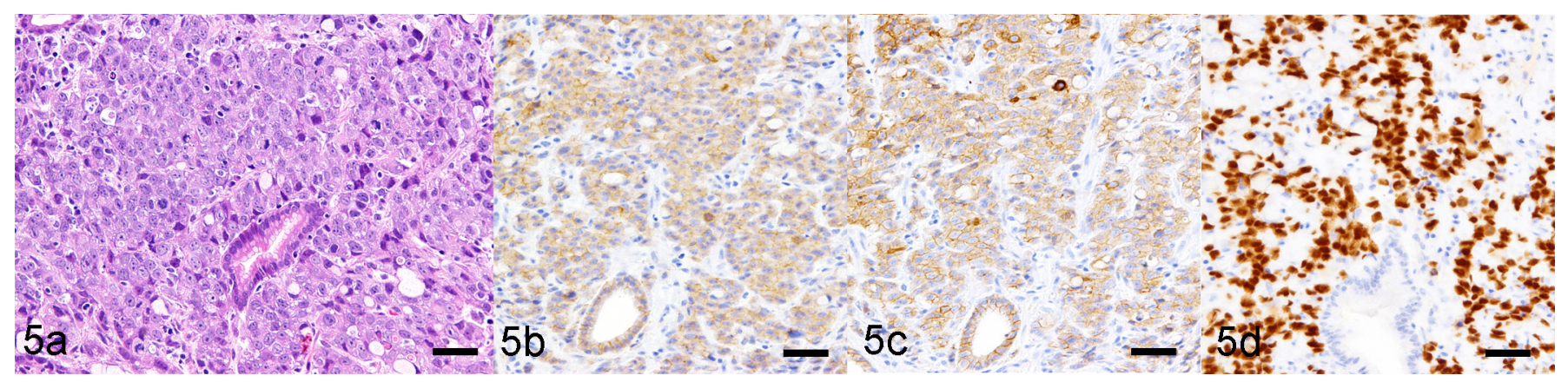

Fig. 5. Undifferentiated carcinoma, sample number 37. Dog, stomach. (a) Neoplastic epithelial cells that show no specific differentiation diffusely proliferate in the lamina propria. Hematoxylin and eosin stain (HE). (b) Nuclei of neoplastic cells are negative for Beta-catenin. Score 0. Immunohistochemistry (IHC). (c) Cell membrane of neoplastic cells is feebly and occasionally positive for E-cadherin. Score 2. IHC. (d) Nuclei of neoplastic cells are strongly and diffusely positive for p53 throughout the lesion. Score 3. IHC. (a-d) Bar, $40 \mu \mathrm{m}$.

MUC (0/7, Fig. 4b) and UND (0/4, Fig. 5b), except for one case in a colorectal NPG tumor. There were statistically significant differences between PG adenocarcinoma and NPG/diffuse type tumors in large intestine.

\section{Immunoreactivity of E-cadherin}

Immunohistochemically, the cell membrane of normal epithelial cells was immunopositive for E-cadherin. The results of E-cadherin immunoreactivity for each tumor are represented in Table 2 and Supplementary Table 1. The immunoreactivity of 
Table 1. Comparison of immunohistochemical profiles of beta-catenin in gastrointestinal tumors

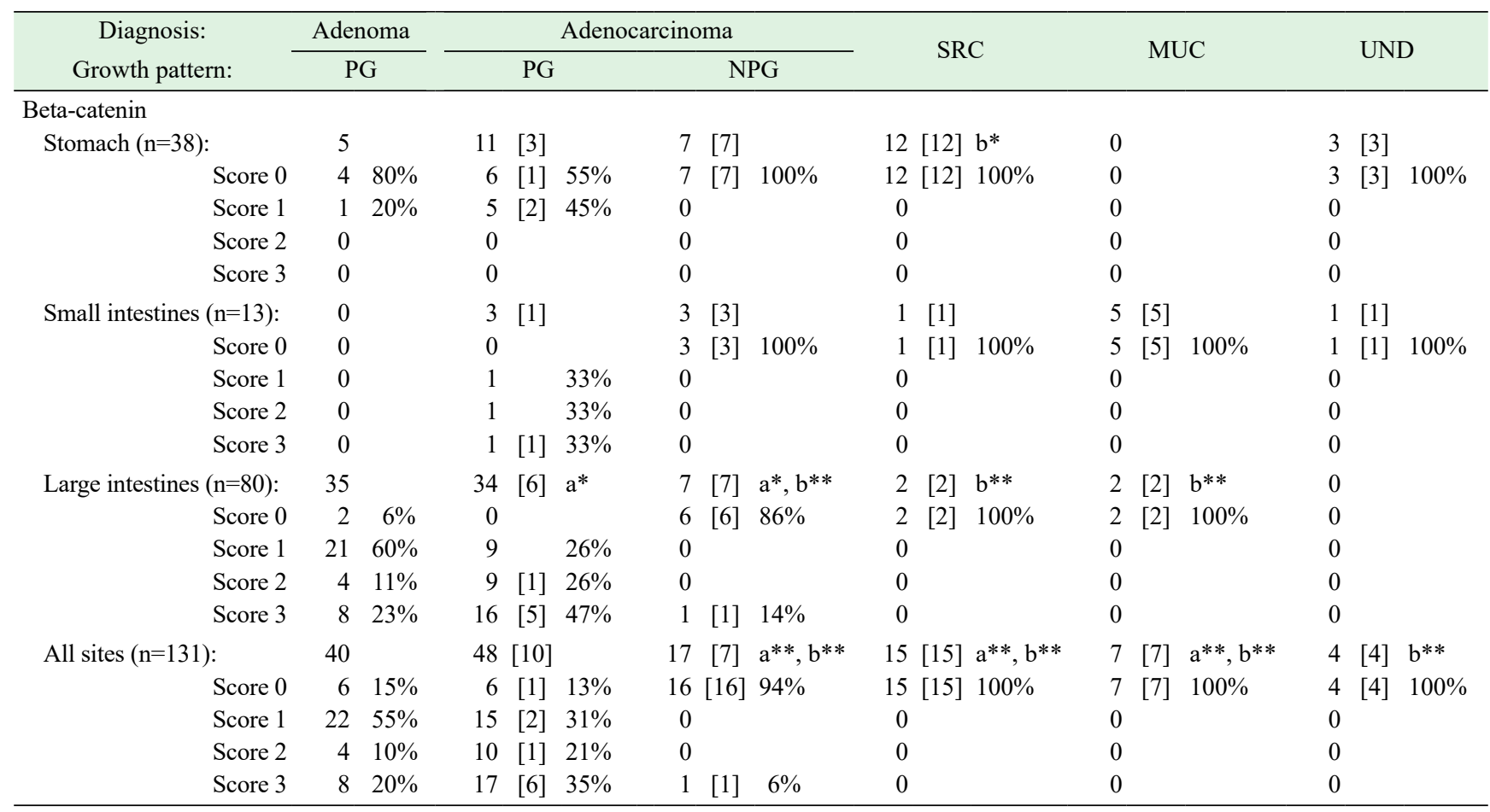

PG, polypoid growth type; NPG, non-polypoid growth type; SRC, Signet-ring cell carcinoma; MUC, Mucinous adenocarcinoma; UND, Undifferenciated carcinoma. The Number of cases showing invasion or metastasis is enclosed in bracket. Statistically significant differences are shown as follows: $\mathrm{a}^{* *}$, $P<0.01$, vs PG adenoma; $\mathrm{b}^{*}, P<0.05$, vs PG adenocarcinoma; $\mathrm{b}^{* *}, P<0.01$, vs PG adenocarcinoma.

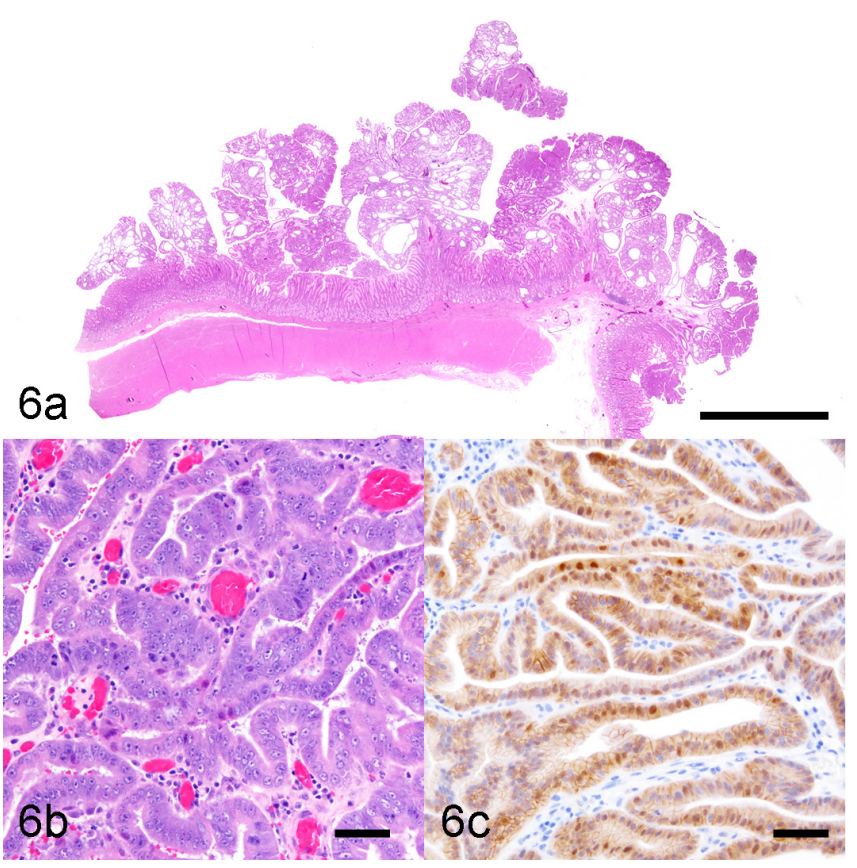

Fig. 6. Polypoid growth type adenocarcinoma, sample number 13. Dog, stomach. (a) Neoplastic epithelial cells prelude into the lumen. Hematoxylin and eosin stain (HE). Bar, $500 \mu \mathrm{m}$. (b) Higher magnification of Fig. 6a. Bar, $60 \mu \mathrm{m}$. (c) Nuclear beta-catenin positive cells are sparsely observed. Immunohistochemistry. Bar, $60 \mu \mathrm{m}$.

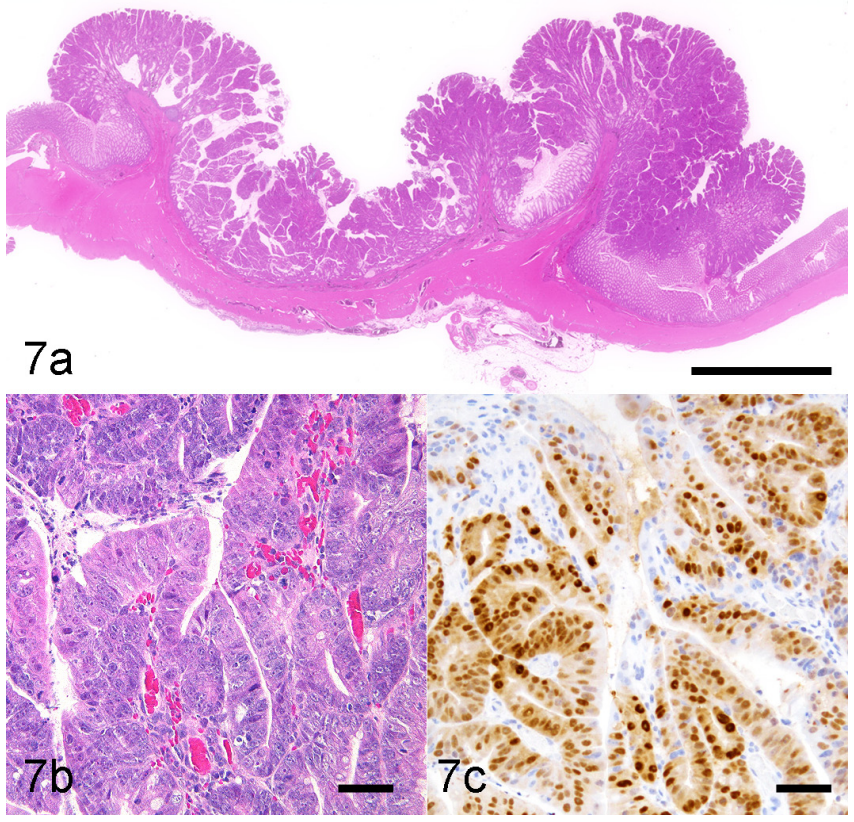

Fig. 7. Polypoid growth type adenocarcinoma, sample number 91 . Dog, intestine. (a) Neoplastic epithelial cells prelude into the lumen. Hematoxylin and eosin stain (HE). Bar, $500 \mu \mathrm{m}$. (b) Higher magnification of Fig. 7a. Bar, $60 \mu \mathrm{m}$. (c) Most of the neoplastic cells show positive for nuclear beta-catenin and high intensity. Immunohistochemistry. Bar, $60 \mu \mathrm{m}$. 
Table 2. Comparison of immunohistochemical profiles of E-cadherin in gastrointestinal tumors

\begin{tabular}{|c|c|c|c|c|c|c|c|c|c|c|c|c|c|c|c|c|c|}
\hline \multirow{2}{*}{$\begin{array}{c}\text { Diagnosis: } \\
\text { Growth pattern: }\end{array}$} & \multirow{2}{*}{\multicolumn{2}{|c|}{$\begin{array}{c}\text { Adenoma } \\
\text { PG }\end{array}$}} & \multicolumn{6}{|c|}{ Adenocarcinoma } & \multirow{2}{*}{\multicolumn{3}{|c|}{ SRC }} & \multirow{2}{*}{\multicolumn{3}{|c|}{ MUC }} & \multirow{2}{*}{\multicolumn{3}{|c|}{ UND }} \\
\hline & & & & PG & & & NP & & & & & & & & & & \\
\hline \multicolumn{18}{|l|}{ E-cadherin } \\
\hline Stomach $(n=38)$ : & 5 & & 11 & {$[3]$} & & 7 & [7] & & 12 & [12] & & 0 & & & 3 & [3] & \\
\hline Score 0 & 1 & $20 \%$ & 0 & & & 0 & & & 0 & & & 0 & & & 0 & & \\
\hline Score 1 & 1 & $20 \%$ & 6 & {$[2]$} & $55 \%$ & 1 & {$[1]$} & $14 \%$ & 0 & & & 0 & & & 0 & & \\
\hline Score 2 & 2 & $40 \%$ & 2 & & $18 \%$ & 4 & {$[4]$} & $57 \%$ & 5 & [5] & $42 \%$ & 0 & & & 2 & [2] & $67 \%$ \\
\hline Score 3 & 1 & $20 \%$ & 3 & [2] & $27 \%$ & 2 & {$[2]$} & $29 \%$ & 7 & [7] & $58 \%$ & 0 & & & 1 & [1] & $33 \%$ \\
\hline Small intestines $(n=13)$ : & 0 & & 3 & {$[1]$} & & 3 & {$[3]$} & & 1 & [1] & & 5 & {$[5]$} & & 1 & [1] & \\
\hline Score 0 & 0 & & 0 & & & 1 & [1] & $33 \%$ & 0 & & & 0 & & & 0 & & \\
\hline Score 1 & 0 & & 0 & & & 0 & & & 0 & & & 1 & {$[1]$} & $20 \%$ & 0 & & \\
\hline Score 2 & 0 & & 2 & {$[1]$} & $67 \%$ & 1 & {$[1]$} & $33 \%$ & 0 & & & 1 & {$[1]$} & $20 \%$ & 0 & & \\
\hline Score 3 & 0 & & 1 & & $33 \%$ & 1 & {$[1]$} & $33 \%$ & 1 & [1] & $100 \%$ & 3 & [3] & $60 \%$ & 1 & {$[1]$} & $100 \%$ \\
\hline Large intestines $(\mathrm{n}=80)$ : & 35 & & 34 & {$[6]$} & & 7 & [7] & $a^{* *}, b^{* *}$ & 2 & [2] & & 2 & [2] & $b^{*}$ & 0 & & \\
\hline Score 0 & 0 & & 0 & & & 0 & & & 0 & & & 0 & & & 0 & & \\
\hline Score 1 & 1 & $3 \%$ & 2 & & $6 \%$ & 2 & {$[2]$} & $29 \%$ & 0 & & & 1 & {$[1]$} & $50 \%$ & 0 & & \\
\hline Score 2 & 10 & $29 \%$ & 5 & {$[1]$} & $15 \%$ & 4 & {$[4]$} & $57 \%$ & 1 & [1] & $50 \%$ & 1 & {$[1]$} & $50 \%$ & 0 & & \\
\hline Score 3 & 24 & $69 \%$ & 27 & {$[5]$} & $79 \%$ & 1 & {$[1]$} & $14 \%$ & 1 & [1] & $50 \%$ & 0 & & & 0 & & \\
\hline All sites $(n=131)$ : & 40 & & 48 & [10] & & 17 & [7] & & 15 & [15] & & 7 & [7] & & 4 & [4] & \\
\hline Score 0 & 1 & $3 \%$ & 0 & & & 1 & {$[1]$} & $6 \%$ & 0 & & & 0 & & & 0 & & \\
\hline Score 1 & 2 & $5 \%$ & 8 & {$[2]$} & $17 \%$ & 3 & [3] & $18 \%$ & 0 & & & 2 & {$[2]$} & $29 \%$ & 0 & & \\
\hline Score 2 & 12 & $30 \%$ & 9 & {$[2]$} & $19 \%$ & 9 & [9] & $53 \%$ & 6 & [6] & $40 \%$ & 2 & {$[2]$} & $29 \%$ & 2 & [2] & $50 \%$ \\
\hline Score 3 & 25 & $63 \%$ & 31 & {$[5]$} & $65 \%$ & 4 & {$[4]$} & $24 \%$ & 9 & [9] & $60 \%$ & 3 & {$[3]$} & $43 \%$ & 2 & [2] & $50 \%$ \\
\hline
\end{tabular}

PG, polypoid growth type; NPG, non-polypoid growth type; SRC, Signet-ring cell carcinoma; MUC, Mucinous adenocarcinoma; UND, Undifferenciated carcinoma. The Number of casess showing invasion or metastasis is enclosed in bracket. Statistically significant differences are shown as follows: $\mathrm{a}^{* *}$, $P<0.01$, vs $P G$ adenoma; $\mathrm{b}^{*}, P<0.05$, vs $\mathrm{PG}$ adenocarcinoma; $\mathrm{b}^{* *}, P<0.01$, vs $\mathrm{PG}$ adenocarcinoma.

E-cadherin for tumor cells tended to decline overall in most of the cases including benign tumors. The immunoreactivity for E-cadherin did not depend on the histological type of the tumors. In PG adenocarcinomas, the surface of the neoplastic foci showed intense immunoreactivity for E-cadherin, whereas the immunoreactivity was reduced in the central area of the neoplastic foci (Fig. 1c). There were no cases that showed the complete loss of immunoreactivity in tumors with glandular or tubular structures of both PG and NPG types (Fig. 2c), whereas NPG types showed statistically lower scores than PG types in the intestine (Table 2). By contrast, the diffuse type carcinomas namely MUC (Fig. 3c), SRC (Fig. 4c) and UND (Fig. 5c) showed severe reduction or complete loss of immunoreactivity for E-cadherin in almost all of the neoplastic lesions (Fig. 4c). In MUC, individual neoplastic cells with signet ring cell-morphology showed obviously reduced reactivity, whereas the cell membrane of the neoplastic tubular structures was intensely immunopositive for E-cadherin (Fig. 3c).

\section{Immunoreactivity of p53}

The normal epithelial cells were completely immunonegative for $\mathrm{p} 53$. The results of $\mathrm{p} 53$ immunoreactivity for each tumor are represented in Table 3 and Supplementary Table 1. A total of $61 \%(80 / 131)$ of the gastrointestinal epithelial tumors, including malignant tumors $(63 \%, 57 / 91)$ were evaluated as score 0 (Fig. 4d). Although about half of gastrointestinal adenomas (43\%, 17/40) had weak and occasional nuclear immunoreactivity for p53, all of these cases were evaluated as score 1 . By contrast, $8 \%$ of the malignant tumors (7/91) exhibited intense immunoreactivity for p53. These tumors including $2 \%$ of PG adenocarcinomas (1/48, Fig. 1d), 6\% of NPG adenocarcinomas (1/17, Fig. 2d), 20\% of SRC (3/15) and 50\% of UND (2/4, Fig. 5d) were evaluated as score 3. In MUC, a small number of neoplastic cells within a limited area of the neoplastic foci showed intense immunoreactivity for p53 (Fig. 3d). We could not definitely conclude significant correlations between histopathological tumor types and immunohistochemical results of p53, although all cases evaluated as score 3 had evidence of interstitial/submucosal invasion or metastasis (Table 3). There was no significant difference between histological growth patterns.

\section{DISCUSSION}

The evaluation of IHC using beta-catenin indicated different results between the gastric and intestinal tumors. All of the PG type adenocarcinomas $(100 \%, 37 / 37)$ in the small and large intestines showed significant nuclear expression of beta-catenin. By contrast, the nuclear expression of beta catenin was obviously rare in PG type adenocarcinomas in the stomach as compared to that in the intestines. The observations suggest that dysregulation of beta-catenin plays an important role in canine intestinal PG type adenocarcinomas, especially in the colorectum. In addition, the different degree of nuclear expression of beta-catenin between gastric and intestinal tumors may indicate the different roles of beta-catenin in the tumorigenesis of these tumors between the 
Table 3. Comparison of immunohistochemical profiles of p53 in gastrointestinal tumors

\begin{tabular}{|c|c|c|c|c|c|c|c|c|c|c|c|c|c|c|c|c|c|}
\hline \multirow{2}{*}{$\begin{array}{c}\text { Diagnosis: } \\
\text { Growth pattern: }\end{array}$} & \multirow{2}{*}{\multicolumn{2}{|c|}{$\frac{\text { Adenoma }}{\text { PG }}$}} & \multicolumn{6}{|c|}{ Adenocarcinoma } & \multirow{2}{*}{\multicolumn{3}{|c|}{ SRC }} & \multirow{2}{*}{\multicolumn{3}{|c|}{ MUC }} & \multirow{2}{*}{\multicolumn{3}{|c|}{ UND }} \\
\hline & & & \multicolumn{3}{|c|}{ PG } & \multicolumn{3}{|c|}{ NPG } & & & & & & & & & \\
\hline \multicolumn{18}{|l|}{ p53 } \\
\hline Stomach $(n=38)$ : & 5 & & 11 & {$[3]$} & & 7 & [7] & & 12 & [12] & & 0 & & & 3 & [3] & \\
\hline Score 0 & 5 & $100 \%$ & 9 & [2] & $82 \%$ & 4 & {$[4]$} & $57 \%$ & 9 & [9] & $75 \%$ & 0 & & & 2 & [2] & $67 \%$ \\
\hline Score 1 & 0 & & 2 & [1] & $18 \%$ & 2 & [2] & $29 \%$ & 1 & {$[1]$} & $8 \%$ & 0 & & & 0 & & \\
\hline Score 2 & 0 & & 0 & & & 0 & & & 0 & & & 0 & & & 0 & & \\
\hline Score 3 & 0 & & 0 & & & 1 & {$[1]$} & $14 \%$ & 2 & {$[2]$} & $17 \%$ & 0 & & & 1 & [1] & $33 \%$ \\
\hline Small intestines $(n=13)$ : & 0 & & 3 & {$[1]$} & & 3 & {$[3]$} & & 1 & {$[1]$} & & 5 & {$[5]$} & & 1 & [1] & \\
\hline Score 0 & 0 & & 2 & & $67 \%$ & 1 & {$[1]$} & $33 \%$ & 0 & & & 2 & {$[2]$} & $40 \%$ & 0 & & \\
\hline Score 1 & 0 & & 1 & [1] & $33 \%$ & 2 & [2] & $67 \%$ & 0 & & & 3 & {$[3]$} & $60 \%$ & 0 & & \\
\hline Score 2 & 0 & & 0 & & & 0 & & & 0 & & & 0 & & & 0 & & \\
\hline Score 3 & 0 & & 0 & & & 0 & & & 1 & {$[1]$} & $100 \%$ & 0 & & & 1 & [1] & $100 \%$ \\
\hline Large intestines $(\mathrm{n}=80)$ : & 35 & & 34 & {$[6]$} & & 7 & {$[7]$} & & 2 & {$[2]$} & & 2 & [2] & & 0 & & \\
\hline Score 0 & 18 & $51 \%$ & 19 & [2] & $56 \%$ & 5 & {$[5]$} & $71 \%$ & 2 & {$[2]$} & $100 \%$ & 2 & {$[2]$} & $100 \%$ & 0 & & \\
\hline Score 1 & 17 & $49 \%$ & 9 & [2] & $26 \%$ & 1 & {$[1]$} & $14 \%$ & 0 & & & 0 & & & 0 & & \\
\hline Score 2 & 0 & & 5 & [1] & $15 \%$ & 1 & {$[1]$} & $14 \%$ & 0 & & & 0 & & & 0 & & \\
\hline Score 3 & 0 & & 1 & [1] & $3 \%$ & 0 & & & 0 & & & 0 & & & 0 & & \\
\hline All sites $(\mathrm{n}=131)$ : & 40 & & 48 & [10] & & 17 & {$[7]$} & & 15 & [15] & & 7 & [7] & & 4 & [2] & \\
\hline Score 0 & 23 & $58 \%$ & 30 & {$[4]$} & $63 \%$ & 10 & [10] & $59 \%$ & 11 & [11] & $73 \%$ & 4 & [4] & $57 \%$ & 2 & [2] & $50 \%$ \\
\hline Score 1 & 17 & $43 \%$ & 12 & [4] & $25 \%$ & 5 & {$[5]$} & $29 \%$ & 1 & {$[1]$} & $7 \%$ & 3 & [3] & $43 \%$ & 0 & & \\
\hline Score 2 & 0 & & 5 & [1] & $10 \%$ & 1 & {$[1]$} & $6 \%$ & 0 & & & 0 & & & 0 & & \\
\hline Score 3 & 0 & & 1 & {$[1]$} & $2 \%$ & 1 & {$[1]$} & $6 \%$ & 3 & [3] & $20 \%$ & 0 & & & 2 & [2] & $50 \%$ \\
\hline
\end{tabular}

PG, polypoid growth type; NPG, non-polypoid growth type; SRC, Signet-ring cell carcinoma; MUC, Mucinous adenocarcinoma; UND, Undifferenciated carcinoma. The Number of casess showing invasion or metastasis is enclosed in bracket. There is no significant difference between growth patterns.

stomach and intestines.

In humans, the pathogenesis of gastric cancer was divided into two categories namely diffuse type and intestinal type, and these are believed to result from distinct pathogenetic pathways $[6,19]$. The intestinal type carcinomas develop after stepwise progression from chronic gastritis to atrophic gastritis, intestinal metaplasia, dysplasia to intestinal type carcinoma. This inflammatory sequence progressing to gastric cancer is particularly prevalent in the gastric tumors caused by Helicobacter pylori (H. pylori) infection [6, 19]. On the other hand, diffuse type tumor is believed to arise as a de novo cancer [19]. Although there are various interpretations of the involvement of dysregulation of the Wnt/beta-catenin pathway in human gastric cancer, Wnt/betacatenin is reportedly involved in more than $30 \%$ of gastric cancers [6].

In the intestinal carcinoma, the adenoma-carcinoma sequence that is associated with multistep gene mutations including APC and beta-catenin dysregulation is the major pathway of the colorectal tumorigenesis in humans [27]. The literature indicated that the intestine is more susceptible to beta-catenin than the stomach, and these classical theories in humans are consistent with the present findings in canine intestinal tumors. In this study, we could not clarify the molecular mechanism of nuclear accumulation of beta-catenin and the roles of genetic mutations including beta-catenin gene or $A P C$. The nuclear accumulation of beta-catenin and $A P C$ mutation have been reported in dogs including, Jack Russell Terrier [62, 63]. Since in the present study the high score of nuclear beta-catenin was also detected in the colorectal tumor of Jack Russell Terrier, mutation of $A P C$ gene of the canine breed might be associated with the phenomena.

In the present study, no nuclear reactivity of beta-catenin was noted in 94\% (16/17) of NPG type carcinomas. Likewise, diffuse type carcinomas including SRC, MUC and UND, the nuclear expression of beta-catenin was not observed. The genetic and molecular factors contributing to NPG type carcinomas remain controversial, and the relationship between beta-catenin and NPG carcinomas also has not been verified. Although APC plays an important role in the degradation of beta-catenin, the molecule is not always involved in NPG carcinomas [60]. The present results in canine tumors indicate that NPG carcinomas including SRC, MUC and UND developed via a pathway that may not require APC/beta-catenin mutation such as the de novo pathway. A previous report describes that beta-catenin played an essential role in canine intestinal tumors [33], however our results indicate that NPG type carcinomas in canine intestines may not require beta-catenin dysregulation for their tumorigenesis.

The immunoreactivity for E-cadherin in epithelial tumors of canine GI tracts was depended on the growth patterns and the location of the neoplastic cells. Namely, in PG type tumors the neoplastic cells on the superficial area facing the luminal space showed intense membrane expression of E-cadherin and the immunoreactivity was markedly reduced or lost in the deeper areas. In addition, some cases of diffuse type carcinomas including SRC, MUC or UND showed complete loss of immunoreactivity for E-cadherin. However, a relationship between the histological pattern and the immunoreactivity for E-cadherin was not clear, because various tumors including benign tumors showed downregulation of E-cadherin. Similar downregulation of E-cadherin 
expression has also been reported in several types of intestinal tumors in both humans [29] and dogs [33]. E-cadherin is essential for the formation and maintenance of normal epithelial structures [45], and most tumors with decreased reactivity of E-cadherin have abnormal cellular architecture and loss of tissue integrity. Hence, our results suggest that downregulation of E-cadherin is involved in the tumor formation of abnormal tissue architecture rather than malignant alteration or invasion in canine gastrointestinal tumors.

The intense immunoreactivity of nuclear p53 was found in a few cases $(9 \%, 7 / 91)$ of gastrointestinal tumors examined in dogs. All these 7 cases were evaluated as score 3 with evidence of malignancy such as invasion or metastasis, while no specific histological patterns were noted in these tumors. Even in some benign tumors, significant immunoreactivity for p53-positive was also observed, while the reactivity score was low and had no evidence of malignancy. Unlike human colorectal tumors, canine malignant behavior was reportedly not accompanied by acquisition of p53 mutations [33, 58]. Our results also suggest that abnormal p53 is not absolutely required in all of the tumors for malignant progression, however, when most of the tumor cells show a high-level of nuclear p53 expression, the tumor may have a high malignant potential.

In conclusion, this experiment provides new insight into the relationship between specific histological patterns and beta-catenin dysregulation in canine intestinal tumors. The nuclear localization of beta-catenin is involved in the development of PG tumors, but not diffuse-types of carcinoma including NPG carcinomas, SRC, MUC and UND. The results suggest that PG adenocarcinomas mainly developed from polypoid adenomas through the conventional adenoma-carcinoma sequence pathway. By contrast, NPG carcinomas may arise thorough different mechanisms, such as the de novo pathway. To conclude the role of E-cadherin and p53 on the tumorigenesis in canine gastrointestinal tumors, further molecular biological studies will be needed.

ACKNOWLEDGMENTS. The authors would like to thank Mr. Pete Aughton, BSc, D.A.B.T., Dip.R.C.Path., ITR Laboratories Canada Inc., for language editing of this paper.

\section{REFERENCES}

1. Ando, K., Oki, E., Saeki, H., Yan, Z., Tsuda, Y., Hidaka, G., Kasagi, Y., Otsu, H., Kawano, H., Kitao, H., Morita, M. and Maehara, Y. 2015. Discrimination of p53 immunohistochemistry-positive tumors by its staining pattern in gastric cancer. Cancer Med. 4: 75-83. [Medline] [CrossRef]

2. Aresu, L., Pregel, P., Zanetti, R., Caliari, D., Biolatti, B. and Castagnaro, M. 2010. E-cadherin and $\beta$-catenin expression in canine colorectal adenocarcinoma. Res. Vet. Sci. 89: 409-414. [Medline] [CrossRef]

3. Berx, G. and van Roy, F. 2009. Involvement of members of the cadherin superfamily in cancer. Cold Spring Harb. Perspect. Biol. 1: a003129. [Medline] [CrossRef]

4. Carrasco, V., Canfrán, S., Rodríguez-Franco, F., Benito, A., Sáinz, A. and Rodríguez-Bertos, A. 2011. Canine gastric carcinoma: immunohistochemical expression of cell cycle proteins (p53, p21, and p16) and heat shock proteins (Hsp27 and Hsp70). Vet. Pathol. 48: 322-329. [Medline] [CrossRef]

5. Chambers, J. K., Saito, T., Fukushima, K., Kakuta, S., Nakayama, J., Ohno, K., Tsujimoto, H., Nakayama, H. and Uchida, K. 2017. Adenocarcinoma of Barrett's esophagus in a dog. J. Toxicol. Pathol. 30: 239-243. [Medline] [CrossRef]

6. Chiurillo, M. A. 2015. Role of the Wnt/ $\beta$-catenin pathway in gastric cancer: An in-depth literature review. World J. Exp. Med. 5: 84-102. [Medline] [CrossRef]

7. Crawford, B. E. and Stromeyer, F. W. 1983. Small nonpolypoid carcinomas of the large intestine. Cancer 51: 1760-1763. [Medline] [CrossRef]

8. Fenoglio-Preiser, C. M., Wang, J., Stemmermann, G. N. and Noffsinger, A. 2003. TP53 and gastric carcinoma: a review. Hum. Mutat. 21: 258-270. [Medline] [CrossRef]

9. Fernandez-Pol, S., Ma, L., Ohgami, R. S. and Arber, D. A. 2017. Immunohistochemistry for p53 is a useful tool to identify cases of acute myeloid leukemia with myelodysplasia-related changes that are TP53 mutated, have complex karyotype, and have poor prognosis. Mod. Pathol. 30: 382-392. [Medline] [CrossRef]

10. Finlay, C. A., Hinds, P. W., Tan, T. H., Eliyahu, D., Oren, M. and Levine, A. J. 1988. Activating mutations for transformation by p53 produce a gene product that forms an hsc70-p53 complex with an altered half-life. Mol. Cell. Biol. 8: 531-539. [Medline] [CrossRef]

11. Frixen, U. H., Behrens, J., Sachs, M., Eberle, G., Voss, B., Warda, A., Löchner, D. and Birchmeier, W. 1991. E-cadherin-mediated cell-cell adhesion prevents invasiveness of human carcinoma cells. J. Cell Biol. 113: 173-185. [Medline] [CrossRef]

12. Gamblin, R. M., Sagartz, J. E. and Couto, C. G. 1997. Overexpression of p53 tumor suppressor protein in spontaneously arising neoplasms of dogs. Am. J. Vet. Res. 58: 857-863. [Medline]

13. Groden, J., Thliveris, A., Samowitz, W., Carlson, M., Gelbert, L., Albertsen, H., Joslyn, G., Stevens, J., Spirio, L., Robertson, M., et al. 1991. Identification and characterization of the familial adenomatous polyposis coli gene. Cell 66: 589-600. [Medline] [CrossRef]

14. Gronostajski, R. M., Goldberg, A. L. and Pardee, A. B. 1984. Energy requirement for degradation of tumor-associated protein p53. Mol. Cell. Biol. 4: 442-448. [Medline] [CrossRef]

15. Haga, S., Nakayama, M., Tatsumi, K., Maeda, M., Imai, S., Umesako, S., Yamamoto, H., Hilgers, J. and Sarkar, N. H. 2001. Overexpression of the p53 gene product in canine mammary tumors. Oncol. Rep. 8: 1215-1219. [Medline]

16. Hasegawa, H., Ueda, M., Furukawa, K., Watanabe, M., Teramoto, T., Mukai, M. and Kitajima, M. 1995. p53 gene mutations in early colorectal carcinoma. De novo vs. adenoma-carcinoma sequence. Int. J. Cancer 64: 47-51. [Medline] [CrossRef]

17. Head, K. W., Cullen, J. M., Dubielzig, R. R., Else, R. W., Misdrop, W., Patnaik, A. K., Tateyama, S. and van der Gaag, I. 2003. Histological classification of tumors of the alimentary system of domestic animals. pp. 73-110. In: World Health Organization International histological classification of tumors of domestic animals. second series. Second series (Schulman, F. Y. ed.), Armed Forces Institute of Pathology in Cooperation with the American Registry of Pathology, Washington, D.C.

18. Hinoi, T., Yamamoto, H., Kishida, M., Takada, S., Kishida, S. and Kikuchi, A. 2000. Complex formation of adenomatous polyposis coli gene product and axin facilitates glycogen synthase kinase-3 beta-dependent phosphorylation of beta-catenin and down-regulates beta-catenin. J. Biol. Chem. 275: 34399-34406. [Medline] [CrossRef]

19. Hugen, S., Thomas, R. E., German, A. J., Burgener, I. A. and Mandigers, P. J. J. 2017. Gastric carcinoma in canines and humans, a review. Vet. 
Comp. Oncol. 15: 692-705. [Medline] [CrossRef]

20. Ichii, S., Horii, A., Nakatsuru, S., Furuyama, J., Utsunomiya, J. and Nakamura, Y. 1992. Inactivation of both APC alleles in an early stage of colon adenomas in a patient with familial adenomatous polyposis (FAP). Hum. Mol. Genet. 1: 387-390. [Medline] [CrossRef]

21. Ikegami, M. 1987. A pathological study on colorectal cancer. From de novo carcinoma to advanced carcinoma. Acta Pathol. Jpn. $37: 21-37$. [Medline]

22. Kadowaki, T., Shiozaki, H., Inoue, M., Tamura, S., Oka, H., Doki, Y., Iihara, K., Matsui, S., Iwazawa, T., Nagafuchi, A., et al. 1994. E-cadherin and alpha-catenin expression in human esophageal cancer. Cancer Res. 54: 291-296. [Medline]

23. Kaklamanis, L., Gatter, K. C., Mortensen, N., Baigrie, R. J., Heryet, A., Lane, D. P. and Harris, A. L. 1993. p53 expression in colorectal adenomas. Am. J. Pathol. 142: 87-93. [Medline]

24. Kikuchi-Yanoshita, R., Konishi, M., Ito, S., Seki, M., Tanaka, K., Maeda, Y., Iino, H., Fukayama, M., Koike, M., Mori, T., et al. 1992. Genetic changes of both $\mathrm{p} 53$ alleles associated with the conversion from colorectal adenoma to early carcinoma in familial adenomatous polyposis and non-familial adenomatous polyposis patients. Cancer Res. 52: 3965-3971. [Medline]

25. Kim, H. C., Kim, H. J. and Kim, J. C. 2002. Reduced E-cadherin expression as a cause of distinctive signet-ring cell variant in colorectal carcinoma. J. Korean Med. Sci. 17: 23-28. [Medline] [CrossRef]

26. Kinzler, K. W., Nilbert, M. C., Su, L. K., Vogelstein, B., Bryan, T. M., Levy, D. B., Smith, K. J., Preisinger, A. C., Hedge, P., McKechnie, D., et al. 1991. Identification of FAP locus genes from chromosome 5q21. Science 253: 661-665. [Medline] [CrossRef]

27. Kinzler, K. W. and Vogelstein, B. 1996. Lessons from hereditary colorectal cancer. Cell 87: 159-170. [Medline] [CrossRef]

28. Kmet, L. M., Cook, L. S. and Magliocco, A. M. 2003. A review of p53 expression and mutation in human benign, low malignant potential, and invasive epithelial ovarian tumors. Cancer 97: 389-404. [Medline] [CrossRef]

29. Kroepil, F., Fluegen, G., Totikov, Z., Baldus, S. E., Vay, C., Schauer, M., Topp, S. A., Esch, J. S., Knoefel, W. T. and Stoecklein, N. H. 2012. Downregulation of $\mathrm{CDH} 1$ is associated with expression of SNAI1 in colorectal adenomas. PLoS One 7: e46665. [Medline] [CrossRef]

30. Kuramoto, S. and Oohara, T. 1988. Minute cancers arising de novo in the human large intestine. Cancer 61: 829-834. [Medline] [CrossRef]

31. Matsui, T., Yao, T., Yao, K., Takenaka, K., Sakurai, T., Iwashita, A., Fuchigami, T., Aoyagi, K. and Date, H. 1996. Natural history of superficial depressed colorectal cancer: retrospective radiographic and histologic analysis. Radiology 201: 226-232. [Medline] [CrossRef]

32. Mayer, B., Johnson, J. P., Leitl, F., Jauch, K. W., Heiss, M. M., Schildberg, F. W., Birchmeier, W. and Funke, I. 1993. E-cadherin expression in primary and metastatic gastric cancer: down-regulation correlates with cellular dedifferentiation and glandular disintegration. Cancer Res. 53: 1690-1695. [Medline]

33. McEntee, M. F. and Brenneman, K. A. 1999. Dysregulation of beta-catenin is common in canine sporadic colorectal tumors. Vet. Pathol. 36: 228-236. [Medline] [CrossRef]

34. Minamoto, T., Sawaguchi, K., Mai, M., Yamashita, N., Sugimura, T. and Esumi, H. 1994. Infrequent K-ras activation in superficial-type (flat) colorectal adenomas and adenocarcinomas. Cancer Res. 54: 2841-2844. [Medline]

35. Minamoto, T., Sawaguchi, K., Ohta, T., Itoh, T. and Mai, M. 1994. Superficial-type adenomas and adenocarcinomas of the colon and rectum: a comparative morphological study. Gastroenterology 106: 1436-1443. [Medline] [CrossRef]

36. Morin, P. J., Sparks, A. B., Korinek, V., Barker, N., Clevers, H., Vogelstein, B. and Kinzler, K. W. 1997. Activation of beta-catenin-Tcf signaling in colon cancer by mutations in beta-catenin or APC. Science 275: 1787-1790. [Medline] [CrossRef]

37. Mueller, J. D., Bethke, B. and Stolte, M. 2002. Colorectal de novo carcinoma: a review of its diagnosis, histopathology, molecular biology, and clinical relevance. Virchows Arch. 440: 453-460. [Medline] [CrossRef]

38. Munemitsu, S., Albert, I., Souza, B., Rubinfeld, B. and Polakis, P. 1995. Regulation of intracellular beta-catenin levels by the adenomatous polyposis coli (APC) tumor-suppressor protein. Proc. Natl. Acad. Sci. USA 92: 3046-3050. [Medline] [CrossRef]

39. Muta, H., Noguchi, M., Kanai, Y., Ochiai, A., Nawata, H. and Hirohashi, S. 1996. E-cadherin gene mutations in signet ring cell carcinoma of the stomach. Jpn. J. Cancer Res. 87: 843-848. [Medline] [CrossRef]

40. Nakamura, Y., Nishisho, I., Kinzler, K. W., Vogelstein, B., Miyoshi, Y., Miki, Y., Ando, H., Horii, A. and Nagase, H. 1991. Mutations of the adenomatous polyposis coli gene in familial polyposis coli patients and sporadic colorectal tumors. Int. Symp. Princess Takamatsu Cancer Res. Fund 22: 285-292. [Medline]

41. Nalbantoglu, I., Blanc, V. and Davidson, N. O. 2016. Characterization of colorectal cancer development in Apc (min/+) mice. Methods Mol. Biol. 1422: 309-327. [Medline] [CrossRef]

42. Nigam, A. K., Savage, F. J., Boulos, P. B., Stamp, G. W., Liu, D. and Pignatelli, M. 1993. Loss of cell-cell and cell-matrix adhesion molecules in colorectal cancer. Br. J. Cancer 68: 507-514. [Medline] [CrossRef]

43. Ochiai, A., Akimoto, S., Shimoyama, Y., Nagafuchi, A., Tsukita, S. and Hirohashi, S. 1994. Frequent loss of alpha catenin expression in scirrhous carcinomas with scattered cell growth. Jpn. J. Cancer Res. 85: 266-273. [Medline] [CrossRef]

44. Ohue, M., Tomita, N., Monden, T., Fujita, M., Fukunaga, M., Takami, K., Yana, I., Ohnishi, T., Enomoto, T., Inoue, M., et al. 1994. A frequent alteration of $\mathrm{p} 53$ gene in carcinoma in adenoma of colon. Cancer Res. 54: 4798-4804. [Medline]

45. Pećina-Slaus, N. 2003. Tumor suppressor gene E-cadherin and its role in normal and malignant cells. Cancer Cell Int. 3: 17. [Medline] [CrossRef]

46. Restucci, B., Martano, M., DE Vico, G., Lo Muzio, L. and Maiolino, P. 2009. Expression of E-cadherin, beta-catenin and APC protein in canine colorectal tumours. Anticancer Res. 29: 2919-2925. [Medline]

47. Rodrigues, N. R., Rowan, A., Smith, M. E., Kerr, I. B., Bodmer, W. F., Gannon, J. V. and Lane, D. P. 1990. p53 mutations in colorectal cancer. Proc. Natl. Acad. Sci. USA 87: 7555-7559. [Medline] [CrossRef]

48. Saito, T., Nibe, K., Chambers, J. K., Uneyama, M., Nakashima, K., Ohno, K., Tsujimoto, H., Uchida, K. and Nakayama, H. 2020. A histopathological study on spontaneous gastrointestinal epithelial tumors in dogs. J. Toxicol. Pathol. 33: 105-113. [Medline] [CrossRef]

49. Shimoda, T., Ikegami, M., Fujisaki, J., Matsui, T., Aizawa, S. and Ishikawa, E. 1989. Early colorectal carcinoma with special reference to its development de novo. Cancer 64: 1138-1146. [Medline] [CrossRef]

50. Shimoyama, Y. and Hirohashi, S. 1991. Expression of E- and P-cadherin in gastric carcinomas. Cancer Res. 51: 2185-2192. [Medline]

51. Shiozaki, H., Tahara, H., Oka, H., Miyata, M., Kobayashi, K., Tamura, S., Iihara, K., Doki, Y., Hirano, S., Takeichi, M., et al. 1991. Expression of immunoreactive E-cadherin adhesion molecules in human cancers. Am. J. Pathol. 139: 17-23. [Medline]

52. Soetikno, R. M., Kaltenbach, T., Rouse, R. V., Park, W., Maheshwari, A., Sato, T., Matsui, S. and Friedland, S. 2008. Prevalence of nonpolypoid (flat and depressed) colorectal neoplasms in asymptomatic and symptomatic adults. JAMA 299: 1027-1035. [Medline] [CrossRef]

53. Tian, X., Liu, Z., Niu, B., Zhang, J., Tan, T. K., Lee, S. R., Zhao, Y., Harris, D. C. and Zheng, G. 2011. E-cadherin/ $\beta$-catenin complex and the epithelial barrier. J. Biomed. Biotechnol. 2011: 567305. [Medline] [CrossRef]

54. Tomita, H., Yamada, Y., Oyama, T., Hata, K., Hirose, Y., Hara, A., Kunisada, T., Sugiyama, Y., Adachi, Y., Linhart, H. and Mori, H. 2007. Development of gastric tumors in $\mathrm{Apc}(\mathrm{Min} /+)$ mice by the activation of the beta-catenin/Tcf signaling pathway. Cancer Res. 67: $4079-4087$. 
[Medline] [CrossRef]

55. Umetani, N., Sasaki, S., Masaki, T., Watanabe, T., Matsuda, K. and Muto, T. 2000. Involvement of APC and K-ras mutation in non-polypoid colorectal tumorigenesis. Br. J. Cancer 82: 9-15. [Medline] [CrossRef]

56. Vleminckx, K., Vakaet, L. Jr., Mareel, M., Fiers, W. and van Roy, F. 1991. Genetic manipulation of E-cadherin expression by epithelial tumor cells reveals an invasion suppressor role. Cell 66: 107-119. [Medline] [CrossRef]

57. Vogelstein, B., Fearon, E. R., Hamilton, S. R., Kern, S. E., Preisinger, A. C., Leppert, M., Nakamura, Y., White, R., Smits, A. M. and Bos, J. L. 1988. Genetic alterations during colorectal-tumor development. N. Engl. J. Med. 319: 525-532. [Medline] [CrossRef]

58. Wolf, J. C., Ginn, P. E., Homer, B., Fox, L. E. and Kurzman, I. D. 1997. Immunohistochemical detection of p53 tumor suppressor gene protein in canine epithelial colorectal tumors. Vet. Pathol. 34: 394-404. [Medline] [CrossRef]

59. Xiangming, C., Hokita, S., Nuruki, K., Toyoyama, H., Tanabe, G., Baba, M., Takao, S. and Aikou, T. 1998. The expression of cadherin-catenin complex in association with the clinicopathologic features of early gastric cancer. Surg. Today 28: 587-594. [Medline] [CrossRef]

60. Yagi, O. K., Akiyama, Y., Ohkura, Y., Ban, S., Endo, M., Saitoh, K. and Yuasa, Y. 1997. Analyses of the APC and TGF-beta type II receptor genes, and microsatellite instability in mucosal colorectal carcinomas. Jpn. J. Cancer Res. 88: 718-724. [Medline] [CrossRef]

61. Yamagishi, H., Kuroda, H., Imai, Y. and Hiraishi, H. 2016. Molecular pathogenesis of sporadic colorectal cancers. Chin. J. Cancer 35: 4. [Medline] [CrossRef]

62. Yoshizaki, K., Hirata, A., Nishii, N., Kawabe, M., Goto, M., Mori, T. and Sakai, H. 2020. Familial adenomatous polyposis in dogs: Hereditary gastrointestinal polyposis in Jack Russell Terriers with germline APC mutations. Carcinogenesis bgaa045. (in press) [Medline] [CrossRef]

63. Youmans, L., Taylor, C., Shin, E., Harrell, A., Ellis, A. E., Séguin, B., Ji, X. and Zhao, S. 2012. Frequent alteration of the tumor suppressor gene APC in sporadic canine colorectal tumors. PLoS One 7: e50813. [Medline] [CrossRef] 